\title{
DUI LISU (DUI MENRE YANG DIKEMBALIKAN) MENURUT PERSPEKTIF HUKUM
}

ISLAM.

Tarmizi

\section{IAIA SENGKANG}

tarmizi@gmail.com

\begin{abstract}
This paper discusses the "Dui Lisu (Dui Menre who is returned) according to the perspective of Islamic law" by revealing the following issues: (1) How to dui lisu with Bugis Traditional law, and (2) How to dui lisu with Islamic law. Dui lisu in view of Bugis custom law is dui menre returned by the women to the men, both returns are half or more. This is because the woman does not fulfill her duty as a wife. Whereas the law of dui lisu according to the Islamic law's view is prohibited. Asking dui lisu is tantamount to asking for a return which in Islamic law is prohibited.
\end{abstract}

Kata kunci: Dui Lisu, Dui Menre, Maslahah.

\section{PENDAHULUAN}

Pernikahan merupakan ikatan lahir dan batin antara laki-laki dengan perempuan menurut ajaran Islam. Dengan adanya ikatan pernikahan maka timbullah hak dan kewajiban suami begitu pula hak dan kewajiban istri. Untuk sahnya pernikahan di dalam ajaran Islam ditentukan dengan beberapa syarat, seperti kedua mempelai, akad, saksi, wali dan mahar. Jika syarat-syarat tersebut tidak terpenuhi maka pernikahan dianggap tidak sah dan percampuran yang dilakukan dianggap sebagai perbuatan zina.

Di dalam adat suku Bugis sering terjadi kekeliruan tentang mahar dan uang belanja (dui menre). Dalam adat perkawinan Bugis, terdapat dua istilah yaitu sompa dan dui menre atau uang panaik atau uang belanja. Sompa atau mahar adalah pemberian berupa uang atau harta dari pihak laki-laki kepada pihak perempuan sebagai syarat sahnya pernikahan menurut ajaran Islam. Sedangkan dui menre atau uang panaik atau uang belanja adalah uang antaran yang harus diserahkan oleh pihak 
keluarga calon mempelai laki-laki kepada pihak keluarga calon mempelai perempuan untuk membiayai prosesi pesta pernikahan. ${ }^{1}$

Oleh sebab itu jika ditinjau dari hukum Islam, hukum asal dari dui menre pada dasarnya boleh (mubah). Berdasarkan kaidah fiqhnya yang berbunyi:

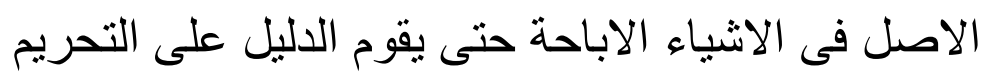

Artinya: Hukum asal dari sesuatu adalah boleh sampai ada dalil yang mengharamkannya. ${ }^{2}$

Demikianlah jika hukum yang dimaksud adalah hukum muamalah maka pada dasarnya semua boleh-boleh saja. Akan tetapi hukum kebolehan tersebut dapat menjadi dilarang jika telah memberatkan, menghalangi pernikahan, dan menimbulkan kerusakan di dalam masyarakat. Karena seringkali terjadi sebuah hubungan tidak lanjut kejenjang pernikahan hanya karena masalah uang panaik. Atau seringkali laki-laki dan perempuan kawin siri karena kurangnya kemampuan laki-laki dalam menyiapkan dui menre. Maka hukum kebolehan dui menre berubah.

Dalam perkembangan selanjutnya, masyarakat seringkali mengalami masalah dalam pernikahan tersebut sehingga terjadilah dui lisu. Dui lisu dimaksud ialah ketika laki-laki meminta $50 \%$ dari dui menre untuk dikembalikan. Hal tersebut dikarenakan perempuan yang dinikahinya menolak sekamar, pergi melarikan diri, perempuan tak menyukai. Dui lisu adalah dui menre yang dikembalikan menurut pandangan dan kebiasaan yang terjadi di masyarakat Bugis.

Islam sebenarnya telah lebih dahulu mengatur pengembalian 50\% dari mahar jika perempuan yang dinikahi belum pernah dicampuri sama sekali. Maka perempuan wajib mengembalikan $50 \%$ dari mahar yang telah diterimanya. Akan tetapi dui menre tidak dapat disamakan/ diqiyaskan dengan mahar. Karena mempunyai perbedaan yang sangat signifikan. Dui menre jika ingin diibaratkan seperti pemberian hadiah, penghargaan, bukti kesungguhan dari laki-laki kepada perempuan.

${ }^{1}$ Syarifuddin dan Ratna Ayu Damayanti "Story of bridge price: Sebuah kritik atas fenomena uang panaik suku Makassar", Jurnal Akuntansi Multiparadigma, Fakultas Ekonomi dan Bisnis Unhas, vol. 6, Nomor 27 April 2015, h. 82

${ }^{2}$ H. A. Djazuli, Kaidah-kaidah Fikih (Cet. V; Jakarta: Kencana Pramedia Group, 2014), h. 51 
Dalam penelitian ini, peneliti hendak membahas tentang Dui Lisu menurut perspektif Islam. Supaya masyarakat mengetahui hukum dui lisu dan semakin memperdalam wawasan tentang kearifan lokal jika dihubungkan dengan hukum Islam. Berdasarkan latar belakang permasalahan di atas, maka yang menjadi pokok masalah yaitu bagaimana dui lisu menurut perspektif hukum Islam. Adapun rincian masalah adalah sebagai berikut Bagaimana dui lisu menurut pandangan adat Bugis dan Bagaimana hukum dui lisu menurut pandangan Islam.

\section{HASIL DAN PEMBAHASAN}

Kata bil Ma'ruf di dalam al-Qur'an diterjemahkan dengan sesuatu yang patut, lazim dilakukan, hal yang sudah terbiasa. Dan bil Ma'ruf ditafsirkan bahwa segala sesuatu yang patut dan sudah terbiasa dilakukan, dalam hal ini diistilahkan dengan budaya, adat atau kearifan lokal. Dengan demikian inti ajaran Islam di dalam al-Qur'an sangat memperhatikan kearifan lokal dalam masyarakat.

Suku bugis mayoritas bertempat tinggal di sulawesi-selatan seperti di Bone, Soppeng, Wajo dan beberapa daerah lainnya. Bugis juga memiliki kekayaan kearifan lokal sebagaimana suku-suku yang ada di Indonesia. Seperti dalam hal pernikahan mulai dari proses melamar, menyebarkan undangan, sampai hari pernikahan berbagai adat bugis dilakukan. Salah satu yang menjadi pokok pembicaraan suku Bugis di dalam proses pelamaran adalah dui menre.

Dui menre dalam adat bugis menjadi hal yang sangat diperhitungkan. Dan bisa dikatakan melebihi posisi mahar dalam pernikahan. Buktinya bisa saja dui menre dua kali lipat dengan mahar, begitu pula seringnya lamaran ditolak hanya karena persoalan dui menre. Masyarakat bugis jika di survey tentang wawasan mahar dan dui menre maka mereka tidak dapat membedakannya bahkan tidak mengetahui hukum kedua komponen tersebut.

Dui menre atau uang panaik adalah uang antaran pihak laki-laki kepada keluarga pihak perempuan untuk digunakan melaksanakan pesta perkawinan. Besarnya dui 
menre ditentukan oleh keluarga perempuan. ${ }^{3}$ Dui menre jumlahnya lebih tinggi daripada jumlah mahar. Saat ini biasanya jumlah dui menre berkisar antara 20 juta hingga ratusan juta tergantung kesepakatan dari kedua belah pihak pada saat negosiasi.

Tolak ukur tingginya dui menre disebabkan beberapa faktor antara lain sebagai berikut:

1. Status sosial keluarga perempuan yang bangsawan atau tidak. Namun untuk sekarang faktor ini sudah tidak terlalu diperhatikan lagi

2. Status ekonomi keluarga pihak perempuan, semakin kaya calon mempelai semakin tinggi pula dui menre yang diminta.

3. Jenjang pendidikan, besar kecilnya dui menre sangat terpengaruh jenjang pendidikan calon istri, apabila pendidikannya hanya tingkat Sekolah Dasar maka semakin kecil pula uang panaik yang dipatok begitu pula sebaliknya jika calon istri lulusan sarjana maka semakin tinggi pula jumlah nominal dui menre.

4. Kondisi fisik calon istri, yang dimaksud ialah paras yang cantik, tinggi badan, dan kulit putih. Semua faktor ini tetap saling tetap saling berhubungan, bisa saja calon istri tidak memiliki paras yang cantik tapi kondisi ekonomi yang kaya, tetap saja dui menre akan tetap tinggi. ${ }^{4}$

Dui menre dipegang oleh orang tua istri untuk membiayai semua kebutuhan jalannya resepsi pernikahan. Tetapi, sebagian masyarakat Bugis Makassar memandang bahwa nilai kewajiban dalam adat lebih tinggi daripada nilai kewajiban syariat Islam. Padahal seharusnya mereka lebih mengedepankan nilai kewajiban syariat Islam daripada nilai kewajiban menurut adat.

Problema yang berkaitan dengan dui menre dalam masyarakat adalah dui lisu. Yang dimaksud dui lisu menurut adat masyarakat Bugis yaitu mengembalikan dui menre yang telah diterima pihak perempuan baik secara keseluruhan atau setengah. Dui lisu yang pernah terjadi dalam masyarakat Bugis ialah mengembalikan setengah $(50 \%)$ atau seperempat $(25 \%)$ dari dui menre yang diterima.

3 Christian Pelras, Manusia Bugis, Nalar bekerjasama dengan Forum Jakarta-Paris EFEO (Jakarta, 2006), h. 180

${ }^{4}$ http://budaya-indonesia-org//Adat-uang-panaik-dalam-pernikahan-Mandar/ 
Nominal dui lisu yang sering terjadi di masyarakat adalah 50\% dari dui menre dengan pertimbangan bahwa pihak perempuan telah menggunakan sebagian dari dui menre tersebut untuk acara pernikahan. Acara pernikahan dalam suku Bugis memang termasuk kategori mewah, biaya tinggi dan ramai. Dengan demikian pihak perempuan yang berposisi sebagai terlamar (objek) membutuhkan biaya pernikahan yang tidak sedikit.

Ada beberapa faktor mendasar yang melatarbelakangi dui lisu ini. Karena disadari bahwa tidak semua pernikahan yang gagal menagih dui lisu kepada pihak perempuan. Ada sebagian yang merelakan dan memang menurut masyarakat Bugis dui menre adalah dui nanre api. ${ }^{5}$ Faktor penyebab dui lisu adalah:

1. Tidak pernah bercampur, pihak laki-laki tidak pernah menyentuh pihak perempuan. Oleh karena itu, pihak laki-laki meminta dui lisu kepada pihak perempuan dengan alasan pihak perempuan tidak melaksanakan kewajibannya.

2. Kekecewaan, pihak laki-laki merasa kecewa dengan pihak perempuan karena tidak disukai. Biasa terjadi di masyarakat Bugis pernikahan dengan paksaan orang tua semata sedangkan sang anak tidak menyukai.

3. Rasa malu kepada keluarga yang lain

4. Adanya bisikan keluarga lain

5. Adanya perjanjian yang dibuat

Faktor penyebab dui lisu pada intinya adalah tuntutan kepada pihak perempuan yang telah mendapat pengorbanan pihak laki-laki yang telah berusaha memberikan dui menre sesuai dengan kesepakatan. Hal tersebut tentunya wajar, karena pihak laki-laki terkadang menjual sawah, pinjam, menggadai untuk semata-mata memenuhi dui menre yang diminta pihak perempuan.

Dalam prakteknya, masyarakat Bugis juga terkadang membuat kesepakatan dan persyaratan sebelum pernikahan. Maksudnya pihak laki-laki dan pihak perempuan membuat perjanjian bahwa jika pernikahan tersebut gagal maka pihak perempuan harus memberikan dui lisu setengah dari dui menre yang telah diberikan. Perjanjian

\footnotetext{
${ }^{5}$ Dui nanre api maksudnya dui yang memang telah dipersiapkan untuk habis.
} 
seperti ini dengan alasan banyaknya pernikahan yang gagal dan untuk memberikan ancaman kepada pihak perempuan untuk menjaga siri' dari pihak laki-laki.

Dui lisu juga dapat berdampak pada pranata sosial masyarakat. Sebagian pihak perempuan sebagai bentuk penyesalan memberikan dui lisu kepada pihak laki-laki untuk setidaknya memperbaiki hubungan keduanya. Karena dui lisu bisa saja menjadi penyebab semakin buruknya hubungan silahturahmi antara kedua belah pihak dalam kehidupan bermasyarakat.

1. Dui Lisu menurut pandangan hukum Islam

Dalam pelaksanaan hukum Islam terdapat dua kategori besar yakni ibadah dan muamalah. Ibadah merupakan hubungan hamba dengan Tuhannya sehingga pelaksanaan tersebut harus jelas sumbernya. Di dalam kaidah fiqhiyyah disebutkan:

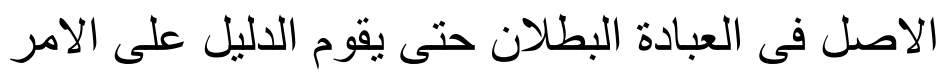

Artinya: Hukum asal dari ibadah adalah batal hingga ada dalil yang menunjukkan kewajiban. ${ }^{6}$

Berbeda dengan masalah ibadah, muamalah merupakan hubungan hamba dengan sesamanya yang pada dasarnya diatur berdasarkan faktor situasi, kondisi dan waktu. Makanya dalam kaidah fiqhiyyah disebutkan:

$$
\text { الاصل فى المعاملة الاباحة حتى يقوم الدليل على التحريم }
$$

Artinya: Hukum asal dari muamalah adalah boleh sampai ada dalil yang menunjukkan keharaman. ${ }^{7}$

Pernikahan termasuk dalam kategori hubungan hamba dengan sesamanya karena melibatkan hubungan antara satu keluarga dengan keluarga lain. Olehnya dui lisu yang terjadi di masyarakat pada dasarnya adalah boleh sampai ada dalil yang mengharamkan hal tersebut. Dalam perkembangan di masyarakat dui lisu mempunyai beberapa bentuk, antara lain:

1. Dui lisu yang diminta secara langsung oleh pihak laki-laki

2. Dui lisu yang secara spontan dikembalikan oleh pihak perempuan

${ }^{6}$ H. A. Djazuli, Kaidah-kaidah Fikih, h. 52

${ }^{7}$ H. A. Djazuli, Kaidah-kaidah Fikih, h. 51 


\section{Dui lisu perjanjian}

Dui lisu dalam bentuk pertama ini hukum kebolehannya masih harus dipertimbangan berdasarkan perspektif Islam. Dui menre yang diminta pada dasarnya dihukum seperti pemberian atau hadiah penghormatan dari pihak laki-laki kepada pihak perempuan sebagai bentuk kesungguhan laki-laki. Di dalam Islam hukum meminta kembali sebuah pemberian/ hadiah adalah tidak boleh. Rasulullah saw bersabda:

حدثا احمد بن عبدة الضبي حدثنا عبد الوهاب النقفي حدثنا ايوب عن عكرمة عن ابن عباس رضي الله عنهما ان رسول الله صلى الله عليه وسلم قال ليس لنا مثل السوء العائد فى هبته كالكلب يعود في قيئه

Artinya: Telah menceritakan kepada kami Ahmad bin Abdah Adh-Dhabbi menceritakan kepada kami, Abdul Wahhab Ats-Tsaqafi menceritakan kepada kami, Ayyub menceritakan kepada kami, dari Ikrimah, dari Ibnu Abbas ra, bahwa Rasulullah saw bersabda, "Kami tidak memiliki contoh yang buruk; Orang yang mengambil kembali pemberiannya seperti anjing yang telah menjilat muntahnya sendiri" (HR. Tirmidzi)

Hadist tersebut menjelaskan tentang larangan meminta kembali pemberian yang telah dimiliki orang lain. Sama halnya dengan meminta dui lisu yang menjadi pemberian pihak laki-laki sebelumnya adalah perbuatan yang dilarang berdasarkan hadist Rasulullah. Dengan hadist ini maka dui lisu dilarang dalam perspektif Islam.

Faktor penyebab larangan meminta dui lisu yang lain adalah karena dengan meminta dui lisu dapat memicu dan menambah kerenggangan kedua belah pihak. Pihak perempuan akan merasa sangat tersisihkan dan terpinggirkan serta akan menanggung siri' yang sangat mendalam pada masyarakat pada umumnya. Padahal spirit Islam adalah menjaga hubungan silahturrahmi baik antara keluarga, masyarakat, maupun manusia secara umum. Di dalam al-Qur'an disebutkan:
8d) of of
1 or of

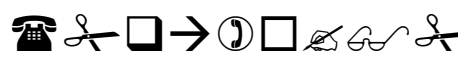

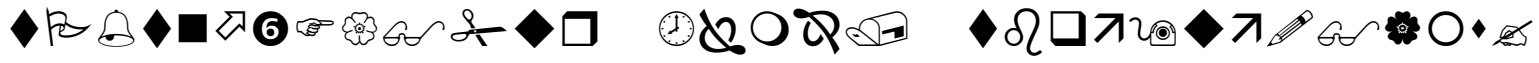

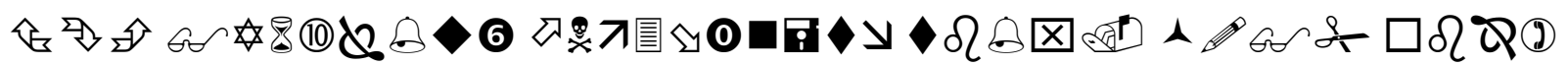


Terjemahannya: dan bertakwalah kepada Allah yang dengan (mempergunakan) nama-Nya kamu saling meminta satu sama lain, dan (peliharalah) hubungan silaturrahim. Sesungguhnya Allah selalu menjaga dan mengawasi kamu. ${ }^{8}$

Dan banyak hadist Rasulullah saw tentang larangan memutuskan silahturahmi, salah satunya beliau pernah bersabda: "Tidak akan masuk syurga orang yang memutuskan silahturahmi". Oleh sebab itu jika dui lisu ini hanya dapat memicu permasalahan yang semakin bertambah dan semakin memutuskan silahturahmi maka dalam Islam hal tersebut dilarang.

Dui lisu dalam bentuk kedua, yakni pihak perempuan sendiri yang berinisiatif untuk mengembalikan sebagian atau seluruh dui menre dari pihak laki-laki maka hukumnya dibolehkan. Dengan melihat kerugian bersama, duka bersama, siri' bersama, maka untuk meringankan siri' dari pihak laki-laki dan untuk memperbaiki hubungan kemanusiaan maka pihak perempuan memberikan dui lisu.

Hal ini merupakan perkara yang baik dan kemaslahatannya sangat jelas. Masyarakat pun dapat menilai bahwa dengan mengembalikan dui lisu secara suka cita pihak perempuan ingin menjaga silahturahmi dengan pihak laki-laki yang telah gagal menjaga ikatan pernikahan mereka. Di dalam ushul fiqh terdapat maslahah mursalah, ${ }^{9}$ yakni kemaslahatan yang tidak secara langsung terdapat dalam al-Qur'an dan Hadist namun ruh dan esensinya sejalan dengan al-Qur'an dan Hadist.

Dui lisu dalam bentuk ketiga, yakni pihak laki-laki dan pihak perempuan melakukan perjanjian tentang dui lisu. Hukum asal dari sebuah perjanjian adalah wajib ditunaikan. Sebuah atsar menyebutkan:

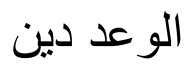

Artinya: Janji adalah hutang

Jika seseorang mempunyai hutang maka ia wajib membayarnya. Begitulah hukum dasar dari sebuah janji, maka dui lisu yang telah disepakati sebelumnya adalah wajib untuk diberikan. Karena yang demikian adalah hutang yang menurut perspektif Islam adalah hal yang wajib ditunaikan, wajib dibayar.

${ }^{8}$ Kementerian Agama RI, Al-Qur'an dan Terjemahan Al-Kaffah, h. 77

${ }^{9}$ Abu Zahra, Usul Fiqh (Kairo: Dar al-Fikr al-Arabiy, tt), h. 277 
Namun menurut peneliti sebelum melakukan perjanjian dui lisu ini harus ada pertimbangan yang kuat. Karena dengan adanya perjanjian dui lisu tersebut sebenarnya secara tidak sadar kedua belah pihak telah memulai pernikahan mereka dengan keraguan. Ragu tidak bisa bahagia, ragu kegagalan pernikahan adalah penyebab dari perjanjian itu. Makanya sangat disarankan untuk perjanjian semacam ini tidak dilakukan. Seyogyanya kedua belah pihak yang melaksanakan pernikahan memulai janji suci mereka dengan keyakinan akan sehidup semati. Dalam istilah orang Bugis "sipuppureng pakkaju sero"10 dan inilah pernikahan yang diperintahkan syariat Islam.

Melakukan perjanjian dui lisu seakan-akan mengukur pernikahan dengan materi semata. Padahal dalam pernikahan tidak hanya tentang materi, disana terdapat tanggungjawab, rela berkorban, harga diri keluarga. Oleh karenanya perjanjian dui lisu sebaiknya ditinggalkan.

Dalam pertimbangan maqasid syariah persoalah maslahah adalah hal yang sangat penting. Semua hukum yang diturunkan Allah swt mempunyai tujuan (maqasid) untuk kemaslahatan manusia di dunia dan di akhirat. ${ }^{11}$ Makanya dalam menimbang problematika dui lisu di masyarakat Bugis harus melihat sisi kemaslahatan manusia.

Salah satu maslahah yang kurang nampak dan tidak tercover dalam maslahah daruriyah yang lima (hidz din, hifdz akl, hifdz nafs, hifdz nasl, dan hifdz al-mal) akan tetapi pembahasannya terdapat dalam kitab klasik adalah hifdz ird. Salah satu ulama yang bernama Ibn Subki menambahkan hifdz ird dalam kategori maslahah daruriyah. Hifdz ird ialah menjaga kehormatan/ harga diri. Sepertinya permasalahan dui lisu ini dapat dipertimbangkan dengan hifdz ird (menjaga kehormatan).

Ibn Subki, menambah satu tujuan syariat lainya, yaitu memelihara kehormatan (hifz al-ird),sehingga disebut al kuliyyah al-sitt. ${ }^{12}$ Sehubungan dengan memelihara

\footnotetext{
${ }^{10}$ Sipuppureng Pakkaju Sero adalah isitilah yang digunakan untuk suami istri yang setia sehidup semati

${ }^{11}$ Izzuddin bin Abd al-Salam, Qawaidh al-Ahkam fi Mashalih al-Anam, Juz II (tt.: Dar al-Jail, 1980), h. 73

12 Tajuddin Ibn Subki, Jam'u al-Jawami bi Hasyiyah al-Bannani, juz II (tt.: Dar al-Ihya al-Kutub alArabiyyah), h. 280
} 
kehormatan diri, yakni harga diri dan gensi, syariat islam mengharamkan berbuat ghibah (mengunjing dan dilarang menuduh ornag berbuat zina dan sebagainya). Dalam hal ini syariat Islam menetapkan had bagi orang yeng menuduh orang yang berbuat zina tersebut secara khusus.

Menjaga kehormatan personal maupun kolektif adalah wajib adanya. Segala macam hal yang dapat mencederai kehormatan dan harga diri seseorang maka hal tersebut dilarang. Makanya di dalam ajaran Islam kedudukan akhlakul karimah sangat penting dan wajib dimiliki setiap pribadi muslim. Dan sebaliknya Islam melarang muslim berakhlak mazmumah yang tidak hanya akan merusak hubungannya dengan Tuhan akan tetapi juga merusak hubungannya dengan masyarakat.

Dui lisu dalam masyarakat bugis dapat mencederai perasaan dan harga diri pihak perempuan. Dui lisu yang diminta pihak laki-laki kepada pihak perempuan menjadi pemicu terputusnya silahruhmi berkepanjangan. Dui lisu yang diminta pihak laki-laki sangat berseberangan dengan maslahah sebaliknya akan mendatangkan mafsadat. Dui lisu tidak sejalan dengan hifdz ird. Kaidah asas menyebutkan:

$$
\text { درء المفاسد مقدم على جلب المصالح }
$$

Artinya: Menolak kerusakan lebih diutamakan daripada mendatangkan kemaslahatan. ${ }^{13}$

\section{A. Kesimpulan}

Setelah uraian dari pembahasan awal sampai dengan pembahasan akhir, berikut ini adalah kesimpulan dari seluruh pembahasan-pembahasan terdahulu yaitu:

1. Yang dimaksud dui lisu menurut adat masyarakat Bugis yaitu mengembalikan dui menre yang telah diterima pihak perempuan baik secara keseluruhan atau setengah. Dui lisu yang pernah terjadi dalam masyarakat Bugis ialah mengembalikan setengah (50\%) atau seperempat (25\%) dari dui menre yang diterima.

2. Dui lisu menurut perspektif hukum Islam pada dasarnya dilarang. Karena dui menre yang diminta untuk dikembalikan (dui lisu) diibaratkan seperti pemberian/ hadiah sedangkan di dalam syariat Islam meminta sebuah pemberian untuk dikembalikan adalah hukumnya dilarang. Sedangkan Dui lisu

${ }^{13}$ H. A. Djazuli, Kaidah-kaidah Fikih, h. 11 
yang diberikan oleh pihak perempuan kepada pihak laki-laki dengan inisiatif sendiri dengan tujuan untuk memperbaiki silahturahmi dan bentuk penyesalan maka hukumnya adalah dibolehkan. Serta dui lisu yang diperjanjikan sebelumnya oleh pihak laki-laki dan pihak perempuan maka hukumnya wajib ditunaikan karena janji dalam syariat Islam adalah wajib ditunaikan. Akan tetapi perjanjian dui lisu antara pihak laki-laki dan pihak perempuan sebaiknya ditinggalkan.

\section{DAFTAR PUSTAKA}

\section{Al-Qur'a>n Al-Kari>m}

Abd. Hakim, Atang \& Mubarok, Jaih. Metodologi Studi Islam. Cet. VII; Bandung: PT. Remaja Rosdakarya, 2003.

Ash-Shiddieqy, Muhammad Hasbi. Pokok-Pokok Pegangan Imam Mazhab. Cet. I; Semarang: PT. Pustaka Rizki Putra, 1997. , Falsafah Hukum Islam. Jakarta: Bulan Bintang, 1986.

Bakri, Asafri Jaya. Konsep Maqashid Syari'ah Menurut al-Syatibi. Jakarta: PT. Raja Grafindo Persada, 1996.

Bin Abd al-Salam, Izzuddin. Qawaidh al-Ahkam fi Mashalih al-Anam, Juz II. tt.: Dar al-Jail, 1980.

Al-Ghaza>li, Abu> Hamid Muhammad bin Muhammad. Al-Mustashfa min 'Ilm alUshu>l. t.t.: Dar al-Fikr, t.th

As-Suyu>thi, Jalaluddin Abdurrahman. Al- Asybah wa An-Nadza>ir. Kairo: Da>r AlKitab Al-Islamiyah, 1978.

Al-Syasthibi, Abu> Ishaq Ibra>him ibn Mu>sa al-Gharnati. al-Muwa>faqa>t fi Ushu>l al-Syari'ah. t.tp: Dar al-Fikr, t.th

H. A Djazuli, Kaidah-Kaidah Fikih. Cet. V; Jakarta: Kencana Prenadamedia Group, 2014.

Ibn Subki, Tajuddin. Jam'u al-Jawami bi Hasyiyah al-Bannani, juz II. tt.: Dar al-Ihya al-Kutub al-Arabiyyah. 
Uways, Abdul Hakim. Fiqh Statis dan Fiqh Dinamis. Cet. I; Bandung: Pustaka Hidayah, 1998.

Abu> Zahra, Muhammad. Ushu>I Fiqh. Kairo: Da>r Al-Fikri Al-Arabiy, 1958.

Al-Zuhai>li>, Wahbah. Nazhariyah al-Dharu>riyah al-Syari>'iyah: Muqa>ranah Ma'a al-Qa>nun al-Wadhi'i. Terj. Said Agil Husein al-Munawar \& M. Hadri Hasan, Jakarta: Gaya Media Pratama, 1997. 